\title{
Plant Growth Promoting Effect and Biocontrol Potential of Rhizobium spp. against Macrophomina phaseolina
}

\author{
Romesh Sagolshemcha $^{1^{*}}$, Yumnam Nganthoi Devi ${ }^{1}$ and W. Robindro Singh ${ }^{2}$ \\ ${ }^{1}$ Department of Life Sciences, Manipur University -795003, India \\ ${ }^{2}$ S.K. Women's College, Kongkhampat Nambol -795134, India \\ *Corresponding author
}

\section{A B S T R A C T}

\begin{tabular}{|c|c|}
\hline Keywords & Nitrogen fixation, siderophore production, phosphate solubilization and \\
\hline $\begin{array}{l}\text { Biocontrol, } \\
\text { Rhizobium, } \\
\text { IAA production, } \\
\text { Phosphate } \\
\text { solubilization, } \\
\text { Macrophomina } \\
\text { phaseolina. }\end{array}$ & $\begin{array}{l}\text { spp. associated with various leguminous plants but the subject needs to be } \\
\text { discussed in more depth. Plant growth promoting effect and biocontrol potential of } \\
\text { nitrogen fixing root nodule isolates from certain leguminous plants of Manipur } \\
\text { was investigated. In present study, nodule isolates associated with ten leguminous } \\
\text { plants from different districts of Manipur were selected. Indole acetic acid (IAA) } \\
\text { production. phosphate solubilization and antagonistic activities of Rhizobium }\end{array}$ \\
\hline Article Info & ains against $M$. phaseolina were evaluated using dual culture technique. Certain \\
\hline $\begin{array}{l}\text { Accepted: } \\
26 \text { May } 2017 \\
\text { Available Online: } \\
\text { 10 June } 2017\end{array}$ & $\begin{array}{l}\text { Rhizobium isolates performed moderately in vitro, for the production of phosphate } \\
\text { solubilization and IAA production. In vitro study revealed that certain Rhizobium } \\
\text { strains effectively reduced the growth of } M \text {. phaseolina by } 50-88 \% \text { inhibition zone } \\
\text { as compared to control. }\end{array}$ \\
\hline
\end{tabular}

\section{Introduction}

Rhizobium promotes the growth of legumes through the formation of nitrogen-fixing nodules. Rhizobia can also associate with roots of non-legumes, without forming true nodules, and can promote their growth by using one or more of the direct or indirect mechanisms of actions. Phytohormone production (Atzorn et al., 1988; Chabot et al., 1996; Yanni et al., 2001; Noel et al.,1996;), secretion of other chemicals like lipo-chitooligosaccharides (Miransari and Smith, 2009;) and lumichrome, solubilization of precipitated phosphorus (Chabot et al., 1996; Yanni et al., 2001; Peix et al., 2001) and mineralization of organic P (Afzal, and Bano,
2008), improvement in uptake of plant nutrients by altering root morphology, production of siderophores (Antoun et al., 1998; Arora et al., 2001; Chabot et al., 1996) to meet the iron requirements of the plant under iron-stressed conditions and lowering of ethylene level through ACC deaminase enzyme, are some examples of the rhizobial mechanisms with direct positive effects on non- leguminous plant growth. Indirectly, rhizobia improve the growth of plants through biocontrol of pathogens via antibiosis, parasitism or competition with pathogens for nutrients and space, by inducing systemic resistance in the host plant and through 
increasing root adhering soil by releasing exopolysaccarides which regulate the water movement and facilitate the root growth. Some Rhizobium spp. have shown antimicrobial activities towards Pseudomonas savastanoi, (Kacem et al., 2009) Aspergillus niger (Yuttavanichakul et al., 2012) Rhizoctonia solani, Fusarium oxysporum and F. solani (El-Batanony et al., 2007), Pythium sp (Bardin et al., 2004; Huang and Erickson, 2007) Phytophthora cinnamomi (Malajczuk et al., 1984) Fusarium solani f. sp. Phaseoli (Buonassisi et al., 1986) Fusarium oxysporum f. sp. Lentis (Essalmani and Lahlou, 2003) with varying degree of growth inhibition. Studies on numerous plantmicrobe interactions have shown that such antagonistic rhizobacteria could function by competition and antibiosis i.e. by producing antimicrobial compounds like bacteriocin (Rodelas et al., 1998; Joseph et al., 1983) but also indirectly by induction of systemic resistance against plant diseases. The potential use of Rhizobium spp. due to their multifaceted beneficial activities is likely to play an important in modern high intensive agricultural practices. In light of the above fact it is proposed to undertake "Plant growth promoting effect and biocontrol potential of Rhizobium spp. against Macrophomina phaseolina" in Manipur.

\section{Materials and Methods}

Survey, collection and preservation of nodule isolates

An intensive survey was conducted at several places of Imphal East District (Andro, Kakwa, Kyamgei, Naharup, Kongba, Moirang Kampu, Jiribam), Imphal West (Manipur University Campus, Chajing, Changangei, Mayang Langjing, Samurou), Thoubal District (Leishangthem, Kakching), Bishnupur District (Khoijuman, Moirang, Nambol Kangmong), Chandel District,
Senapati District (Mao), Ukhrul District (Kachai), Tamenglong District for collection of root nodules from certain leguminous plants viz., Psophocapus tetraglonolobus, Cajanus cajan, Canavalia gladiata, Sesbania sesban, Lablab purpureus, Pisum sativum, Vicia faba, Vigna umbelata, Phaseolus vulgaris, Phaseolus lunatus found in Manipur.

\section{Isolation and characterization}

Soil was caring and gently removed from root materials of the plant. Nodules were then washed with running tap water to remove any soil and plant debris. Nodule shape, size, type, number and location of the nodules on the root system of the host plants were recorded. Healthy and intact nodules were selected randomly and immersed in glass beakers containing 95\% ethanol (or isopropanol) for 5-10 sec to break surface tension and to remove air bubbles from nodule tissues. They were then transferred to a 3-5\% (v/v) solution of sodium hypochloride for $5 \mathrm{~min}$ and washed 4-5 times in sterile distilled water.

Each surface sterilized nodule from different legumes was crushed with a sterile glass rod in a test tube containing $1 \mathrm{ml}$ distilled water with $0.5 \% \mathrm{NaCl}$. One loopful of the nodule suspension was streaked on Petri plates containing Yeast extract mannitol agar (Congo red/Bromothymol Blue as an indicator) to obtain a pure isolated colony and incubated at $28{ }^{\circ} \mathrm{C}$ for 7-10 days and make daily observations for the appearance of typical colonies of rhizobia.

The purity of the isolates were checked by microscopic examination and authenticated by testing the capacity of typical isolates to form nodules on roots from which the isolates were obtained. Pure cultures of the Rhizobia were stored on YEMA (Yeast Extract Mannitol Agar) slants for further use. 


\section{Phosphate solubilization by test bacteria}

The Rhizobium strains were tested for their ability to dissolve phosphate under in vitro conditions using NBRIP media (Glucose 10g, $\mathrm{Ca}_{3}\left(\mathrm{PO}_{4}\right)_{2} 5 \mathrm{~g}, \mathrm{MgCl} \cdot 6 \mathrm{H}_{2} \mathrm{O} 5 \mathrm{~g}, \mathrm{KCl} 0.2 \mathrm{~g}$, $\left(\mathrm{NH}_{4}\right)_{2} \mathrm{SO}_{4} 0.1 \mathrm{~g}, \mathrm{MgSO}_{4} \cdot 7 \mathrm{H}_{2} \mathrm{O} 0.25 \mathrm{~g}$, Agar $15 \mathrm{~g}$, distilled water $1 \mathrm{lt})$. The strains were spot inoculated on the medium, and $\mathrm{P}$ solubilisation was checked by measuring the zone of clearance.

Assay for indoleacetic acid (IAA) production

Quantitative IAA productionin liquid culture was determined colorimetrically. $72 \mathrm{hr}$ old cultures of Rhizobium strains grown in $100 \mathrm{ml}$ YEM for $72 \mathrm{~h}$ at $30^{\circ} \mathrm{C}$ at $120 \mathrm{rpm}$ were centrifuged at $5000 \mathrm{rpm}$ for $30 \mathrm{~min}$. The supernatant $(50 \mu \mathrm{l})$ was mixed with $450 \mu \mathrm{l}$ phosphate buffer. Development of pink colour indicates IAA production.From this mixture $60 \mu \mathrm{l}$ was added to $440 \mu \mathrm{l}$ of phosphate buffer in a tube containing $500 \mu \mathrm{l}$ of Salkowski reagent $\left(12 \mathrm{~g}\right.$ of $\mathrm{FeCI}_{3}$ per litre of $7.9 \mathrm{M}$ $\mathrm{H}_{2} \mathrm{SO}_{4}$ ). Red color formation was quantified as the absorbance at a wavelength of $540 \mathrm{~nm}$ in a spectrophotometer. The amount of IAA produced per milliliter of culture was estimated using a standard curve.

\section{Fungal isolates}

Macrophomina phaseolina culture was provided by Indian Institute of Agricultural Research, New Delhi. The culture was maintained on Potato Dextrose Agar at $27^{\circ}$ $\pm 1^{\circ} \mathrm{C}$. The stock culture of the fungus was kept at for long term storage at $4^{\circ} \mathrm{C}$.

\section{Screening and bioassay for antagonistic} activity of effective rhizobial strain

In vitro antifungal assay was performed using the dual culture techniques. The bacterial isolates tested for their antifungal activity were fully grown in the YEM broth media. Test fungi were grown on Potato Dextrose agar plates (PDA). 5 days old mycelial discs (5mm dia.) of Macrophomina phaseolina were placed at 2 sides from the center on PDA. Exponentially grown Rhizobial isolate was spot inoculated at the center. The distance between the fungus and the Rhizobia was kept at $2.5 \mathrm{~cm}$. Inhibition radial growth of test fungus was observed daily. Culture plates with the test fungus only served as control. In each case three (3) replicates were taken. The petriplates were incubated at $26 \pm 1^{\circ} \mathrm{C}$ in B.O.D. incubator for five days. The diameters of the colonies were measured after five days and average values compared with control were taken as a measure of fungitoxicity. Growth inhibition (\%) of test fungus was determined by using the formula quoted by Pani and Patra (1997).

$\begin{aligned} & \text { Growth Inhibition } \\ & \text { percentage }\end{aligned}=\frac{\text { Control }- \text { Test x } 100}{\text { Control }}$

\section{Results and Discussion}

\section{Isolation and characterization of nodule isolates}

Physical and biochemical characterization of nodule isolates from different leguminous plants was performed. The rhizobia isolated from Psophocapus tetraglonolobus, Cajanus cajan and Lablab purpureus exhibited slow growth rate and showed white colour colony on YEMA (BTB indicator) indicating as nonRhizobium colony. However, the nodule isolates from Canavalia gladiata, Sesbania sesban, Pisum sativum, Vicia faba, Vigna umbelata, Phaseolus vulgaris and Phaseolus lunatus exhibited a fast growing yellow colour colony with thick mucous which indicated as Rhizobium colony. All the nodules isolates were Gram negative, motile, non-spore forming, non-capsulated, rod shaped and aerobic but could grow under anaerobic condition. The cells were between 
$0.9-1.2 \mu \mathrm{m}$ in diameter and $2-3 \mu \mathrm{m}$ in length. Growth was evident in temperatures between $10-42^{\circ} \mathrm{C}$ and $\mathrm{pH} 6-10$; optimum growth was observed in $28-36^{\circ} \mathrm{C}$ and $\mathrm{pH} 7$ 8 . The nodule isolates were authenticated by reinoculation of the Rhizobial isolates with the host legumes. The rhizobial isolates were inoculates with the surface sterilize host legumes seed and grown in Leonard's Jar and inside plant growth chamber.

\section{Phosphate solubilisation and Indole acetic acid (IAA) production}

The rhizobial strains were determined for phosphate solubilizing and IAA production in the culture media (Table 1). Among 10 (ten) rhizobial strains tested only 2 (two) strains were found to exhibit negative result for phosphate solubilisation in the culture media. The remaining 8 (eight) rhizobial strains showed positive result with various degree of phosphate solubilisation in the NBRIP media. However positive result of IAA production in the culture media were observed in all 10 (ten) rhizobial strain tested.

Antagonistic effect of rhizobial strains against Macrophomina phaseolina

Two hundred and ten (210) rhizobial strains were screened for the antagonistic effect against Macrophomina phaseolina. Not all the rhizobial strain exhibited antagonistic effect against the test fungi. In the present study Rhizobium isolates associated with root nodules of Cajanus cajan, Pisum sativum, Vicia faba, Vigna umbelata, Phaseolus vulgaris, Phaseolus lunatus exhibited antagonistic effect against the test fungi.

In vitro antifungal bioassay of ten (10) most effective rhizobial strains was tested against Macrophomina phaseolina and different result were observed. None of the Rhizobia showed complete growth inhibition of the test fungi but exhibited significant growth reduction. The highest percentage of growth inhibition rate of Macrophomina phaseolina was observed from the nodule isolate RHIVUMU09 (88.86\%) followed by RHIVUA24 (80.91\%) and RHIPSMU76 (72.76\%) (Table 2).

The symbiotic association between leguminous plant and the rhizobia is beneficial for both the host plant and the rhizobia. The rhizobia not only provide nitrogen source to the host plant but also promote the growth of the plant by producing plant growth hormone like IAA, inhibition of plant pathogen, making phosphate available to the plant, etc.

Table.1 Biochemical properties of the rhizobial strains

\begin{tabular}{ccccc}
\hline $\begin{array}{c}\text { Nodule } \\
\text { Isolate Code }\end{array}$ & $\begin{array}{c}\text { Phosphate } \\
\text { solubilzation }(\mathbf{m m})\end{array}$ & $\begin{array}{c}\text { Growth }(\mathbf{O D} \\
\text { at 540nm) }\end{array}$ & $\begin{array}{c}\text { IAA }\left(\boldsymbol{\mu g} \mathbf{~ m l}^{\mathbf{1}}\right) \\
\text { production }\end{array}$ & $\begin{array}{c}\text { Specific productivity } \\
\text { (IAA production/ } \\
\text { growth) }\end{array}$ \\
\hline RHIPSMU76 & $3 \pm 0.04$ & 1.92 & 129.2 & 67.29 \\
RHIPSS & $4 \pm 0.03$ & 1.63 & 35.9 & 22.02 \\
RHIPSK & $3 \pm 0.02$ & 1.90 & 96.1 & 50.58 \\
RHIVUMU09 & $5 \pm 0.12$ & 1.67 & 87.8 & 52.57 \\
RHIVUA & $5 \pm 0.04$ & 1.82 & 52.5 & 28.84 \\
RHICCMU & $2 \pm 0.02$ & 1.69 & 67.9 & 40.18 \\
RHIVFK & - & 1.68 & 101.2 & 60.23 \\
RHIVFNK & - & 1.49 & 69.3 & 46.51 \\
RHIPVK & $2 \pm 0.14$ & 1.80 & 76.4 & 42.44 \\
RHIPLMU23 & $4 \pm 0.09$ & 1.72 & 90.7 & 52.73 \\
\hline
\end{tabular}


Table.2 In vitro antifungal activity of effective rhizobial strains against Macrophomina phaseolina

\begin{tabular}{llll}
\hline Sl. No. & Nodule Isolates Code & Fungal colony diameter $(\mathbf{c m})$ & Inhibition $(\boldsymbol{\%})$ \\
\hline 1 & Control & $8.70 \pm 0.20$ & \\
2 & RHIPSMU76 & $2.37 \pm 0.21$ & 72.76 \\
3 & RHIPSS21 & $2.68 \pm 0.30$ & 69.19 \\
4 & RHIPSK16 & $2.44 \pm 0.16$ & 71.87 \\
5 & RHIVUMU09 & $0.97 \pm 0.12$ & 88.86 \\
6 & RHIVUA24 & $1.66 \pm 0.22$ & 80.91 \\
7 & RHICCMU01 & $3.49 \pm 0.14$ & 59.83 \\
8 & RHIVFK21 & $3.34 \pm 0.14$ & 61.66 \\
9 & RHIVFNK16 & $2.94 \pm 0.17$ & 66.23 \\
10 & RHIPVK13 & $3.22 \pm 0.14$ & 62.96 \\
11 & RHIPLMU23 & $4.10 \pm 0.17$ & 52.87 \\
\hline & SEM & $\mathbf{0 . 1 6}$ & \\
\hline
\end{tabular}

The inhibition of fungal growth of the test fungi in vitro by certain of the rhizobia and formation of inhibition zones were presumably due to the metabolites released by the bacteria into the culture medium. These metabolites may include antibiotics and/or cell-wall degrading enzymes. Different studies have implicated antifungal secondary metabolites produced by Rhizobium spp. in the control of plant diseases caused by pathogenic fungi (Ehteshamul- Haque and Ghaffar, 1993; Siddiqui et al., 2000). Previous studies suggest that rhizobia possessing the traits of volatiles, cyanide production, and phosphate solubilisation can increase plant growth (Glick et al., 1995). Indeed, some P-solubilising organisms have been reported as plant growth promoters, but rigorous proof is lacking (De Freitas et al., 1997; Whitelaw et al., 1997). Different studies have indicated that phosphate solubilisation may play a key role in plant growth promotion (Chabot et al., 1996). The strains of Rhizobium leguminosarum biovar viceae and MesoRhizobium sp. nodulating chickpea were the most effective solubilisers of phosphate (Halder et al., 1990). Although the basic mechanisms behind such protection are not clearly defined, the possibility that competition, antibiosis, direct parasitism and induced resistance by the antagonistic bacteria, may operate synergistically after inoculation with effective Rhizobium isolates cannot be ruled out.

The present study can be concluded as i) different isolates performed moderately in vitro, for the production of phosphate solubilization and IAA production and ii) certain nodules isolates were able to form inhibition zones in vitro against Macrophomina phaseolina, suggesting the production of antibiotics. The present study suggests that the effective rhizobia could be used effectively as biocontrol agents against Macrophomina phaseolina and they could be fielded within an integrated disease management package.

\section{Acknowledgement}

The corresponding author wish to thank DST/SERB, Government of India for funding Fast Tract Young Scientist Scheme project "Biocontrol potentials of Rhizobium spp. against plant pathogens and symbiotic interaction with certain non-leguminous plants" (SB/YS/LS-69/2013 dated 
19/09/2013) during this tenure the work was conducted. Thanks are also due to DBT Advance Level Biotech Hub at S.K. Women's College Nambol, Manipur where the experiment was conducted.

\section{References}

Afzal, A., and Bano, A. 2008. Rhizobium and phosphate solubilizing bacteria improve the yield and phosphorus uptake in wheat (Triticum aestivum). Int $\mathrm{J}$ AgricBiol 10:85-88

Antoun, H., C. J. Beauchamp, N. Goussard, R. Chabot, and Lalande, R. 1998. Potential of Rhizobium and BradyRhizobium species as growth promoting rhizobacteria on non-legumes: effect on radishes (Raphanus sativus L.). Plant Soil 204: 57-67.

Arora, N. K., S. C. Kang, and Maheshwari, D.K. 2001. Isolation of siderophoreproducing strains of Rhizobium meliloti and their biocontrol potential against Macrophomina phaseolina that causes charcoal rot of groundnut. Curr Sci 81(6):673-677

Atzorn, R., A. Crozier, C. T. Wheeler, and Sandberg, G. 1988. Production of gibberellins and indol-3-acetic acid by Rhizobium phaseoli in relation to nodulation of Phaseolus vulgaris roots. Planta 175:532-538

Bardin, S.D., H. C. Huang, J. Pinto, E. J. Amundsen, and Erickson, R.S. 2004. Biological control of Pythium dampingoff of pea and sugar beet by Rhizobium leguminosarum bv. viceae. Canadian Journal of Botany, 82(3): 291-296

Buonassisi, A.J., R. J. Copeman, H. S. Pepin, and Eaton, G.W. 1986. Effect of Rhizobium spp. on Fusarium solani f. sp. phaseoli. Canadian Journal of Plant Pathology. 8(2): 140-146

Chabot, R., H. Antoun, and Cescas, M.P. 1996a. Growth promotion of maize and lettuce by phosphate-solubilizing Rhizobium leguminosarum biovar phaseoli. Plant and
Soil, 184: 311-321,

De Freitas J.R., M. R. Banerjee, and Germida J. J. 1997. Phosphate solubilizing rhizobacteria enhance the growth and yield but not phosphorus uptake of canola (Brassica napus L.). Biology Fertilizer Soils 24: 358-364.

Ehteshamul-Haque S., and Ghaffar A.1993. Use of rhizobia in the control of root rot diseases of sunflower, okra, soybean and mungbean. Journal of Phytopathology 138: 157-163.

El-Batanony, N. H., O. N. Massoud, M. M. Mazen, and El-Momum, M. M. A. 2007. The inhibitory effects of cultural filtrates of some wild Rhizobium spp. on some faba bean root rot pathogens and their antimicrobial synergetic effect when combined with arbuscular mycorrhiza (Am). World J. Agric. Sci. 3(6): 721-730

Essalmani, H., and Lahlou, H. 2003. Bioprotection mechanisms of the lentil plant by Rhizobium leguminosarum against Fusarium oxysporum $\mathrm{f}$. sp. lentis. Comptes Rendus Biologies 326 (12):1163-1173

Glick. B.R., D. M. Karaturovic, and Newell P.C., 1995. A novel procedure for rapid isolation of plant growth promoting Pseudomonas. Canadian Journal of Microbiology 41: 533-536.

Halder A.K., A. K. Mishra, P. Bhattacharayya, and Chakrabartty P.K., 1990. Solubilization of rock phosphate by Rhizobium and BradyRhizobium. Journal of General and Applied Microbiology 36: 81-92.

Huang, H.C., and Erickson, R.S. 2007. Effect of seed treatment with Rhizobium leguminosarum on Pythium damping-off, seedling height, root nodulation, root biomass, shoot biomass, and seed yield of pea and lentil. Journal of Phytopathology. 155(1):31-37.

Joseph, M.V., J. D. Desai, and Desai, A. J. 1983. Production of antimicrobial and bacteriocin-like substances by Rhizobium trifolii. Appl. Environ. Microbiol. 45: 2532-535 
Kacem, M., F. Kazouz, C. Merabet, M. Rexki, Lajudie de Philippe and Bekki, A. 2009. Antimicrobial activities of Rhizobium sp strains against Pseudomonas savastanoi, the agent responsible for the olive knot disease in Algeria. Grasasaceites, 60(2): 139-146

Malajczuk, N. M. Pearce, and Litchfield, R.T. 1984. Interactions between Phytophthora cinnamomi and Rhizobium isolates. Transactions of the British Mycological Society, 82(3): 491-500

Miransari, M., and Smith, D. 2009. Rhizobial lipo-chito oligosaccharides and gibberellins enhance barley (Hordeum vulgare L.) seed germination. Biotechnology, 8(2): 270-275

Noel, T.C., C. Sheng, C. K. Yost, R. P. Pharis, and Hynes, M. F. 1996. Rhizobium leguminosarum as a plant growthpromoting rhizobacterium: direct growth promotion of canola and lettuce. Canadian Journal of Microbiology, 42(3): 279-283

Peix, A., A. A. Rivas-Boyero, P. F. Mateos, C. Rodri'guez-Barrueco, E. Martı'nezMolina, and Velazquez, E. 2001. Growth promotion of chickpea and barley by a phosphate solubilizing strain of MesoRhizobium mediterraneum under growth chamber conditions. Soil Biol Biochem 33: 103-110

Rodelas, B., J. Gonzalez-Lopez, V. Salmeron, M. V. Martinez-Toledo, and Pozo, C. 1998. Symbiotic effectiveness and bacteriocin production by Rhizobium leguminosarum bv. viceae isolated from agricultural soils in Spain. Applied Soil
Ecology, 8(1-3): 51-60

Siddiqui I.A., S. Ehteshamul-Haque, M. J. Zaki, and Ghaffar A., 2000. Greenhouse evaluation of rhizobia as biocontrol agent of root infecting fungi in Okra. Acta Botanica 53: 13-22.

Pani, B. K. and Patra, A. K. 1997. Utilization of some phytoextracts of $S$. rolfsii during paddy straw mushroom cultivation a new approach. Mushroom Res., 6(1): 37-41.

Whitelaw M. A., T. J. Harden, and Bender G. L., 1997. Plant growth promotion of wheat inoculated with Penicillium radicum sp. Australian Journal of Agricultural Research 35: 291-300.

Yanni, Y.G., R. Y. Rizk, F. K. Abd El-Fattah, A. Squartini, V. Corich, A. Giacomini, F. De Bruijn, J. Rademaker, J. Maya-Flores, P. Ostrom, M. Vega-Hernandez, R. I. Hollingsworth, E. Martinez-Molina, P. Mateos, E. Velazquez, J. Wopereis, E. Triplett, M. Umali-Garcia, J. A. Anarna, B. G. Rolfe, J. K. Ladha, J. Hill, R. Mujoo, P. K. Ng, and Dazzo, F.B. 2001. The beneficial plant growth-promoting association of Rhizobium leguminosarum bv. trifolii with rice roots. Australian J Plant Physiol 28: 845-870.

Yuttavanichakul, W., P. Lawongsa, S. Wongkaew, N. Teaumroong, N. Boonkerd, N. Nomura, and Tittabutr, P. 2012. Improvement of peanut rhizobial inoculant by incorporation of plant growth promoting rhizobacteria (PGPR) as biocontrol against the seed borne fungus, Aspergillus niger. Biological Control, 63(2): 87-97.

\section{How to cite this article:}

Romesh Sagolshemcha, Yumnam Nganthoi Devi and Robindro Singh, W. 2017. Plant Growth Promoting Effect and Biocontrol Potential of Rhizobium spp. against Macrophomina phaseolina. Int.J.Curr.Microbiol.App.Sci. 6(6): 2695-2701. doi: https://doi.org/10.20546/ijcmas.2017.606.320 